\title{
Women's Value in a Social Capital Context: a Net Present Social Value Analysis
}

\author{
Kosy Timothy Nwosu ${ }^{\# 1}$, Gerry Gatawa ${ }^{\# 2}$ \\ ${ }^{l}$ MBA Graduate, Department of Business Administration, Saint Louis University, Baguio City, Philippines. \\ ${ }^{2}$ Dr. Prof. Department of Business Administration, Saint Louis University, Baguio City, Philippines.
}

\begin{abstract}
Social capital is formed from individual abilities through the social investment that contributes to value creation where individuals feel a sense of membership and commitment through their social interactions and relationships. This study aims to explore the application of social capital to women's organizations. It further explores the net social value of women's organizations and the women members to determine social capital's role as a means for value creation. At these ends, the mixed method was employed by combining qualitative and quantitative data gathering approaches. The study used key informant interviews among 11 women's organizations in Baguio City and Benguet, where a total of 284 women members were interviewed. The result of the talks was subjected to semantic analysis and net present social value analysis. The results reveal that women's organizations reflect the dimensions of social capital and bring a significant contribution to members' lives. The findings imply that women members are duly recognized in their organizations, and each member expects to receive a positive value of the social benefit. Hence, women's organizations are the embodiment of social capital that contributes to women's value creation and empowers their members to maximize their capacities.
\end{abstract}

Keywords: Nigeria, Philippines, Dimensions of Social Capital, Women, Value creation.

\section{INTRODUCTION}

A thorough understanding of societies formed based on the social capital concept elevates one's view of social capital's relevant role in many societies' efficient functioning. these societies are in the form of communities, networks, groups, or organizations where they operate and interact using their abilities and contributed resources (Grooart, 1998). Their established social norms often guide their interactions, and they shift into personal sharing, reciprocity, and trustworthiness (Putnam, 2000).

They primarily act as a social network that provides support to the members, and in return, the members have a feeling of belongingness and commitment (Huntsman, 2006).

The core of societies formed as social capital is building-up interpersonal relationships among individuals in which they share their desire to achieve a specific goal. the most valuable to them are family, friends, associates, allies, or contracts. these were seen as 'safety nets,' and the end benefits derived from joining these societies (Woolock, 1998).

Social capital is embodied in most collective actions. women participate in collective action with the aspiration that they can become better in terms of social and economic conditions. Having their children and their desire for better living conditions have been their biggest motivations to involve themselves in social networks (arrivallage,2014).

Women's organizations play a vital role in the community and in the lives of their members. according to Mpanje et al (2018), women's organizations are active in organizing meetings to tackle issues related to community, culture, and politics. They engage in helping vulnerable women through vocational training and microcredit programs. women's organizations help mobilize resources in order to empower women through income from group projects, raising their living standards, and providing psychological fulfillment through belonging to specific groups. examples of income generating activities include selling of farm produce, cash from labor activities, and cash from their husbands (Wambua, 2013). 
DOI: $\underline{10.51386 / 25815946 / \mathrm{ijsms}-\mathrm{v} 4 \mathrm{i} 3 \mathrm{p} 115}$

Volume: 4 Issue: 3

May to June 2021

www.ijjsmsjournal.org

feminist groups have also been instrumental in combating social and political injustices. they have been working on topics such as women's education, the abolition of child marriage, and law changes to prevent women from being treated unfairly. they also fought for women's spiritual and material advancement, as well as equality of rights and opportunities, on many occasions (Jeanings, 1993). Female's organizations are interested in the provision of infrastructure amenities in order to pursue development projects that are aimed at pursuing economic development and educational empowerment of women members, according to Odurukwe, et al. (2007), they have been granting loans for business growth, offering scholarships to members' and community's children, and providing health and child care services.

\section{LITERATURE REVIEW}

Women's organizations in the Philippines and Nigeria have similarities in which they arise due to and gender issues. These organizations serve as a vehicle for women for social, political and economic empowerment (Heja, 2009). In the Philippines, women's organizations exist to raise awareness of gender issues and fight against abuses such as sexual violence, reproductive rights and sexuality. The advocates intended to formalize the organizations of as entities in order to translate the theoretical understanding into more concrete pragmatic actions (Arum, 2010). They thrived in the country and supported non-governmental organizations, raised awareness of gender issues and women's livelihood activities. Women's organizations have continuously progressed and become dynamic to support their members even during the Philippines (Heja, 2009).

Women's associations in Nigeria are used to empower women who are frustrated with patriarchal systems and gender inequality. The patriarchal system was deeply ingrained, resulting in inequality in access to formal education, political and economic participation, and increased rates of violence such as prostitution, forced marriage, and human trafficking. Nigeria's plight has forced women into a vulnerable position, necessitating immediate attention. Women's organizations and mobilization, according to Arum (Heja, 2009), have ensured the harmony and sustainability of women's social and economic lives. During the pre-colonial years in Niger, women were completely engaged in government life and had access to domestic wealth (Soriola, 2017).

Odurukwe et al., (2007) in their study shows that women's development organizations / are formed at different levels and have different relationships with each other. While Olojede (208) was able to influence the infrastructures and other development programs that contribute to the economic development of the community due to the high rate of involvement of these organizations of these women.

Social capital has been broadly considered and contextualized in numerous societal viewpoints; this can range from politics to economics, social justice, and disaster recovery to business perspectives. The role of women in community growth and human advancement is essential. Therefore, the Social capital dimensions are considered an essential element for human and economic development.

Essential in the success of a provision of an intervention is group trust. For instance, Putnam shows the value of trust and social status by offering micro-finance to a group of women under a group-based credit scheme. Inside the group, social pressure and group members would not want to risk their reputation as a community.

Maclean (2010), has highlighted the value of creating social capital and the various aspects in which women members use microfinance services. The research reveals how shared, and mutual traditions-based networks have access to capital and are essential to development and survival. Reciprocity networks are also regarded as necessary for the development and subsistence of agriculture. Land ownership acts as a critical resource because it creates trust and long-term stability. As this could damage their prestige and endanger their social capital, which is considered more worthy than a commercial activity, women do not participate in competitive commercial practices. Women's social capital (in the view of a women's group) was specifically valued as a loan guarantee in providing microfinance. It was targeted at encouraging capitalization and sound financial management.

Ganapati (2012) has examined social capital's benefits for women disaster survivors. Civic networks were instrumental for women to overcome the psychological impacts of the disaster and empowered women, and overcome public assistance stigma. It contends that making women's formal and informal networks become more visible in the literature; enhances social capital studies, mostly filling the gap on gender dimensions. The chosen indicators for dimensions will be inputs to estimating the NPSV (net present social value) of women. 
While NPSV (Jeanings, 1993) has been used in a few experiments, few organizations have attempted to measure it because not all projects have social value. Arguments and problems persist in quantifying social value (or social benefits), and the discount rate is given subjectively in most of the NPSV calculation.

According to Jennings (1993), the social value can be created by the organization providing the services itself with the funds, or by the organization spending the money and using the proceeds to buy services on the open market (the free market has pricing mechanisms, and the price stands for the value of the service).

The monetary and social value (or social benefits) of investments must be evaluated using the NPSV model to the pretest of non-profit (NFP) health care facilities (Wheeler, 1990). Computing the stream benefit and cost of an organization's is helpful using the methodological proposal. Social results should be precisely described, valued, and recorded to equity capital suppliers or funders-lifetime Zoubida Allaoua; World Bank (2001).

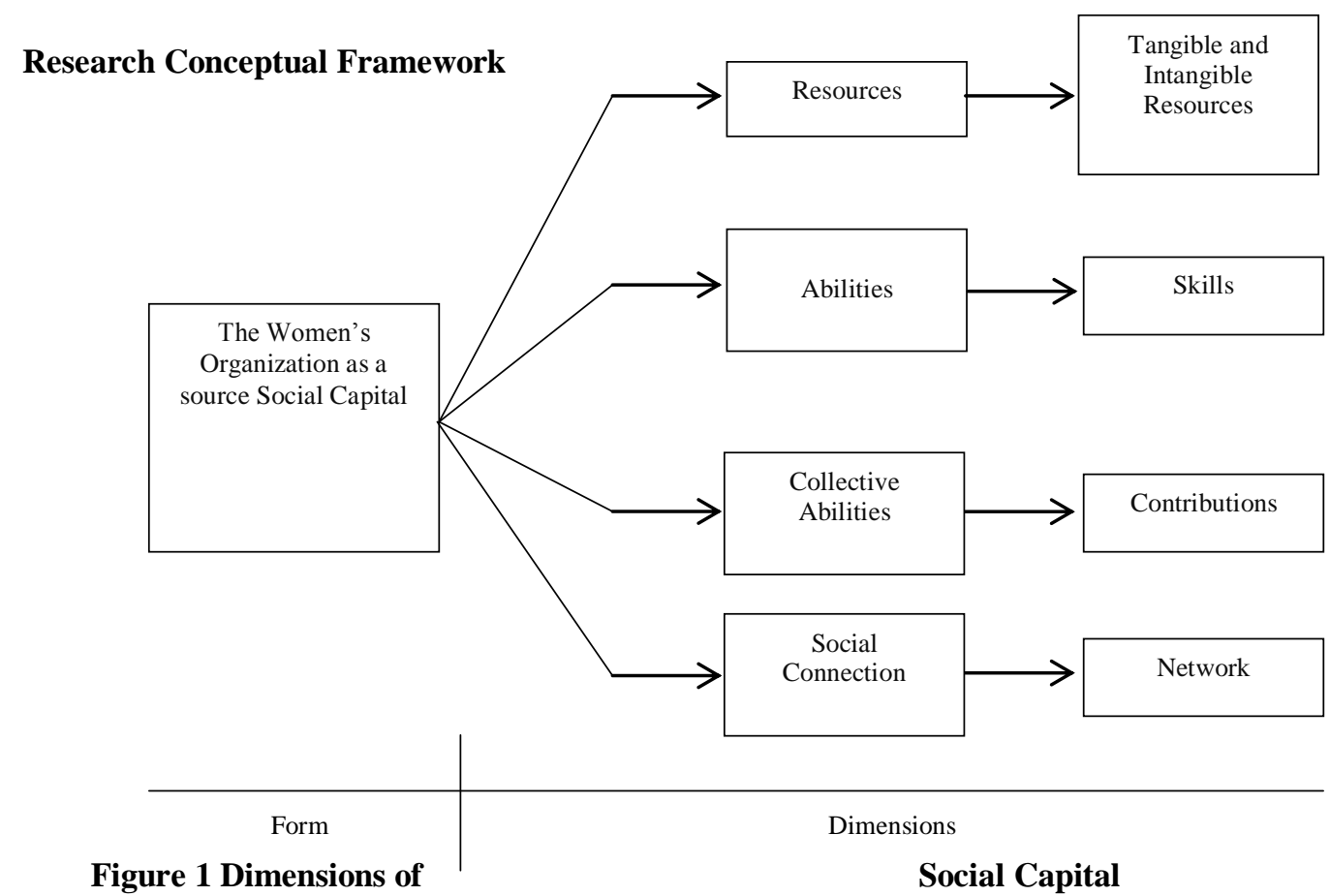

Social Capital appears to have dimensions, and these dimensions are conceptual distinctions that are useful for analytic convenience. Social capital transforms into resources its dimensions in the form of collective abilities such as each individual's contribution; social connection such as the network one belongs to; and the individual's abilities as a member in an organization.

The dimensional social capital model developed in the communitarian approach is a practical approach to investigate the complex social capital concept. Narayan and Cassidy (2001) identify a range of dimensions. The social capital dimensions are integrated to show how these aspects are linked. Tsai and Ghoshal (1998) demonstrate how each dimension of social capital enhances the development of other dimensions and stresses the significance of interpersonal networks. This also means that investing in social capital creation through these dimensions creates value for the organization. (Putnam, 1993). For instance, merely developing civil society groups do not automatically cause the concurrent introduction of social capital inside and amongst these new civil society businesses. As a substitute, efforts to build social capital have to consider the various social capital resources and stem from these families, schools, local communities, firms, civil society, public sector, gender, and ethnicity (OECD, 2001). 
DOI: $\underline{10.51386 / 25815946 / \mathrm{ijsms}-\mathrm{v} 4 \mathrm{i} 3 \mathrm{p} 115}$

Volume: 4 Issue: 3

May to June 2021

www.ijjsmsjournal.org

\section{METHODOLOGY AND METHODS}

The research is a cross-sectional descriptive correlational design through the use of triangulation method. Particularly, it employs the use of questionnaires and interview guide to gather qualitative and quantitative data. First, the qualitative data was used because it provides the advantage of presenting a holistic picture of an individual's thoughts, feelings, and experience (Parry et al., 2014). In the study context, the data gathered are those experiences, thoughts, and feelings of the managers or women's organization leaders who are most likely involved in their respective organizations' day-to-day activities. The Qualitative data provide descriptive data as manifested in the respondents' written or spoken words and observable behaviors (Taylor, Bogdan \& DeVault, 2015). Additionally, quantitative data could give direct answers to research questions. It establishes objectivity, replicability, validity, and reliability, whereby the researcher can interpret the meanings of data by enriching it through literature reviews and personal reflections and experiences (Cypress, 2017).

Sample size of the study: Individuals who are member of women organizations for more than two years in Baguio City and in Benguet province was employed to be part of this study. They were managers and officers of the women organizations. Thereafter on the basis of the inclusion criterion two City was selected, Baguio City and Benguet City where researcher administered the tools to the respondents to check comprehensibility. The sample comprised of At least two hundred eighty-four (284) members who were eager to participate through written and oral interviews. The researchers aimed at maximizing the number of respondents, the implementation of quarantine protocols within the different Barangays in Baguio City has caused some limitations. However, the researcher exerted all his efforts in gathering data for the entire month of September 2020.

The Key Informant Interview Guide (KIIG) and Questionnaire: This tool is developed by the researchers. After establishing rapport with the women organizations in Baguio and Benguet City, only eleven (11), and 284 two hundred and eighty-four members approved the interview and willingly shared information about their organization after, they were requested to fill out the informed consent form and were assured of confidentiality. To protect their identity no name was mentioned and consequently, respondents gave verbal and written consent and approval. In this research, it followed the procedure of Frey (2018), and they are as follows: (1) conduct of repeated review; (2) analysis of data appropriate for the study; (3) interpretation of the construction being analyzed to achieve clarification and scientific understanding; (5) triangulation of data from other sources (e.g., interviews, observations, surveys); and (6) corroboration, elucidation or extension of results to guard against bias through other data sources.

\section{RESULTS AND DISCUSSION}

1.The Women's Organizations as a Source of Social Capital - The respondents presented the number of their years of existence, purpose, their purpose, vision/mission, members/clients, and respective activities.

Table 1: The Women's Organization as a source of Social Capital

\begin{tabular}{|l|l|}
\hline Variables & Key Informant's Explanation and Point of Views \\
\hline Years of & $4 ; 5 ; 6 ; 3 ; 2 ; 24 ; 42 ; 7 ; 9 ; 10 ; 11$ ( Mean $=11.18)$ \\
\hline Puistence & \\
\hline & "Bringing back tradition." \\
\cline { 2 - 2 } & "To help women." \\
\cline { 2 - 2 } & "To pull resources together." \\
\cline { 2 - 2 } & "To train ladies." \\
\cline { 2 - 2 } & "Extra income for the family." \\
\cline { 2 - 2 } & "To encourage cooperation." \\
\cline { 2 - 2 } & "Support women." \\
\cline { 2 - 2 } & "To promote unity." \\
\cline { 2 - 2 } & "To assist the low-income earners." \\
\cline { 2 - 2 } & "To...identify ourselves." \\
\hline Vision/ & "To put ethnic apparel." \\
\cline { 2 - 2 } Mission & "Help women to have a good future and living." \\
\cline { 2 - 2 } & "... to reach a major number of the populace." \\
\hline
\end{tabular}


DOI: $\underline{10.51386 / 25815946 / i j s m s-v 4 i 3 p 115}$

Volume: 4 Issue: 3

May to June 2021

www.ijjsmsjournal.org

\begin{tabular}{|c|c|}
\hline & "Improvement of member's standard of living." \\
\hline & "...to empower indigenous women to self-reliance." \\
\hline & "Let the women know what, who they are." \\
\hline & "An association anchored with respect, honesty, and camaraderie." \\
\hline & "... an environment where the low-income earners can live in the society comfortably..." \\
\hline & "To help members to put up a business...to help their families." \\
\hline & $\begin{array}{l}\text { "...to establish our market outlet...to become competitive producers of women's } \\
\text { products..." }\end{array}$ \\
\hline Members/ & "Indigenous who wants to learn or invest in sewing..." \\
\hline Clients & "locals, friends, and families, single mothers." \\
\hline & "Women...who are poised and willing to join and generate resources." \\
\hline & "Students and community people, and family and friends." \\
\hline & "Friends, relatives, home and abroad, market people, and walk-ins." \\
\hline & "33 [indigenous women]" \\
\hline & "Any woman who wants to be a member..." \\
\hline & "Mostly, women, but we include our...female children." \\
\hline & "Women of ibaloi, kankanaey and kalanguya." \\
\hline Activities & "meetings, seminars, and workshops... a party like gathering...sponsor some kids." \\
\hline & $\begin{array}{l}\text { "Medical missions; providing essential needs of members; cooking lessons; free check-up } \\
\text { for members; and gardening." }\end{array}$ \\
\hline & $\begin{array}{l}\text { "Monthly contribution...to execute the organizational plan; .... weekly reach out in the } \\
\text { society." }\end{array}$ \\
\hline & "Daily cloth making and design planning." \\
\hline & "Weaving, sewing, selling the products." \\
\hline & "...skills training and seminars." \\
\hline & "...monthly meeting...to talk about problems and find solutions..." \\
\hline & "Creating livelihood, conduct meetings...; seminars..." \\
\hline & "...giving out donation...outreach program." \\
\hline & "...ask members to share their business idea...conduct meetings..." \\
\hline
\end{tabular}

The details of this Table 1, brought about five specific areas in Women's Organizations as a Source of Social Capital. they have existed for several years (Mean=11.18 years), indicating that women organizations can operate for longer years when they support their organization and their members. Another area is that, women organizations to pursue their purpose, vision and mission, they create relevant activities geared towards the members' social and economic development. Also, they generally provide training and skills development, which open venues for livelihood opportunities for women members to uplift their socio-economic conditions. the women organizations reveal the richness of social capital in society. It shows that the women organizations came together and shared their common goals and plans in mutual understanding. Moreover, they promoted equality and fairness in terms of behavior and opportunities in the community by providing access to vulnerable groups through their significant activities such as helping the members earn income, attending training and development, and having access to microloans could help in building economic independence. This study is supported and validated by McEloy (200) who posits that social capital tends to value relationships and inherently manifest trust, reciprocity, shared values, networking, and norms.

2. The Women as a Source of Social Capital - Stephenson (2018), affirms that the strength of social capital entities is rooted in their members' contribution since the management can utilize these contributed resources to attain their purpose. This women's perceptions of their organization's participation are positive $(M=4.03, n=11)$. The results of the survey show that women are actively involved in the organization's activities and make significant contributions of both tangible and intangible resources. They contribute both tangible and intangible resources, such as money and other assets, as well as time, effort, and support. 
DOI: $\underline{10.51386 / 25815946 / \mathrm{ijsms}-\mathrm{v} 4 \mathrm{i} 3 \mathrm{p} 115}$

Volume: 4 Issue: 3

May to June 2021

www.ijjsmsjournal.org

Table 2: The Resources Contributed by Women to Their Organization: Tangible and Intangible

\begin{tabular}{|c|c|c|c|c|c|c|c|c|}
\hline \multirow{2}{*}{ No. } & \multirow[b]{2}{*}{ Indicator } & \multicolumn{5}{|c|}{ Frequency } & \multirow[b]{2}{*}{$\begin{array}{l}\text { Wtd. } \\
\text { Mean }\end{array}$} & \multirow[b]{2}{*}{$\begin{array}{l}\text { Desc. } \\
\text { Equiv. }\end{array}$} \\
\hline & & $\begin{array}{l}5- \\
\text { VH }\end{array}$ & $\begin{array}{l}\text { 4- } \\
\text { H }\end{array}$ & $\begin{array}{l}\text { 3- } \\
\mathbf{N}\end{array}$ & $\begin{array}{l}2- \\
\text { L }\end{array}$ & $\begin{array}{l}\text { 1- } \\
\text { VLL }\end{array}$ & & \\
\hline 1 & $\begin{array}{l}\text { In terms of tangible resources (example: } \\
\text { monetary, equipment, etc.) }\end{array}$ & 2 & 3 & 6 & 0 & 0 & 3.64 & $\mathrm{H}$ \\
\hline 2 & $\begin{array}{l}\text { In terms of intangible resources (example: } \\
\text { time, effort, support, participation, etc.) }\end{array}$ & 3 & 8 & 0 & 0 & 0 & 4.27 & $\mathrm{VH}$ \\
\hline 3 & $\begin{array}{l}\text { Individual ability (example: expertise, skill, } \\
\text { suggestions, etc.) }\end{array}$ & 2 & 7 & 2 & 0 & 0 & 4.00 & $\mathrm{H}$ \\
\hline 4 & $\begin{array}{l}\text { Teamwork, the building of trust with } \\
\text { members of the organization }\end{array}$ & 4 & 3 & 4 & 0 & 0 & 4.00 & $\mathrm{H}$ \\
\hline 5 & $\begin{array}{l}\text { Contribution in the aspect of social network } \\
\text { (example: support to the group, pursuing } \\
\text { collective effort) }\end{array}$ & 3 & 6 & 2 & 0 & 0 & 4.09 & $\mathrm{H}$ \\
\hline 6 & $\begin{array}{l}\text { Interpersonal skills such as emotional } \\
\text { support to other members }\end{array}$ & 4 & 4 & 3 & 0 & 0 & 4.09 & $\mathrm{H}$ \\
\hline 7 & $\begin{array}{l}\text { Human capital (example: labor, services } \\
\text { rendered) }\end{array}$ & 3 & 6 & 2 & 0 & 0 & 4.09 & $\mathrm{H}$ \\
\hline \multicolumn{7}{|c|}{ Overall Mean } & 4.03 & $\mathbf{H}$ \\
\hline
\end{tabular}

Surprisingly, the underlying capacities and contributions of women members determine the success of women organizations. The women's organizations were able to pursue their specified purposes as a result of their commitment to the mission and vision of their organizations, as shown in the results. They are eager to contribute whatever resources they have, both tangible and intangible. Kamasaki (2017) reveals that women's organization's success is determined by their willingness to contribute either in the form of tangible or intangible resources.

3.The Individual Abilities of Members in Women's Organization- as observed in their basic profiles. The themes created were related to character, skills, reasons for membership, and their efforts in the organization. The remarkable individual abilities of women members in their respective organizations. When they joined the organizations, they possess individual character and skills that were eventually honed when they became members.

Table 3: The Individual Abilities of Members in a Women's Organization

\begin{tabular}{|c|c|c|}
\hline Variables & Respondent's Explanation and Point of Views & Respondent \\
\hline \multirow[t]{5}{*}{ Character } & "Willingness...community engagement." & $\begin{array}{l}\text { R1, R5, R6, } \\
\text { R10 }\end{array}$ \\
\hline & "...love what you are doing." & R2, R11 \\
\hline & $\begin{array}{l}\text { "Women... who want to pull their resources together... who also want to } \\
\text { offer better ideas in running the organization..." }\end{array}$ & $\mathrm{R} 3, \mathrm{R} 8$ \\
\hline & "Must have a passion for training... ability to communicate." & $\mathrm{R} 4, \mathrm{R} 9$ \\
\hline & "As long as you are a woman, single or married...you have the interests." & R7 \\
\hline \multirow[t]{5}{*}{ Skills } & "...with or without a degree and most have skills..." & $\begin{array}{l}\text { R1, R7, R9, } \\
\text { R10 }\end{array}$ \\
\hline & "...to learn skills like sewing and cooking." & R2, R6 \\
\hline & $\begin{array}{l}\text { "...with an elementary school certificate... also those with higher } \\
\text { education..." }\end{array}$ & R3 \\
\hline & "...handwork in terms of vocational study..." & $\mathrm{R} 4, \mathrm{R} 8$ \\
\hline & "...know how to sew, weave, pattern and cutting." & R5, R11 \\
\hline Efforts & $\begin{array}{l}\text { "[1] exceptionally active when it comes to running the organization or } \\
\text { when tasks are given; [2] we lift each other by making use of our products; }\end{array}$ & $\mathrm{R} 1$ \\
\hline
\end{tabular}




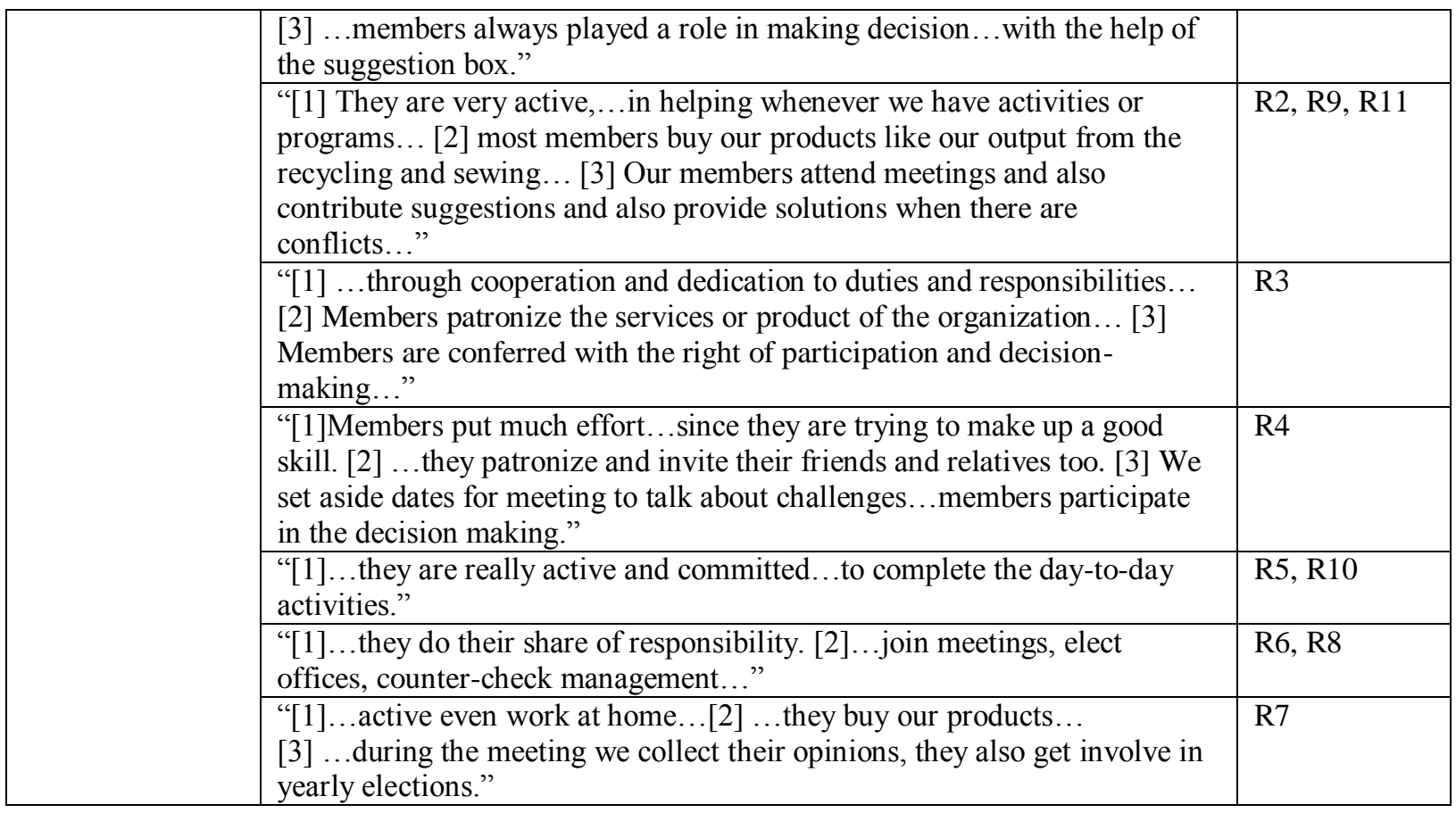

Through the aid of the women organizations, they collectively contributed their character and skills and developed the drive to exert effort to support their organization. Conceptually, a woman carries individual abilities, but she could be weak to achieve results if she is alone. However, when she becomes part of a social entity, she can impart her individual abilities and maximize her potential to contribute to a bigger purpose. Similarly, Burke and Collins(2001) echoes that a woman could be capacitated to use her abilities and skills in an organization where she is recognized and appreciated for her capacities. The result is further corroborated by Burke and Collins (2001) who underscore women's trait as being more cooperative, change-oriented, problemsolver, inspired, and assertive when their organization enhances their individual abilities and utilize them for a greater purpose.

4. The Collective Abilities of Women's Organizations - In general, the women extended the socio-economic contributions they made to their members in which they were able to elevate the confidence of their members and their earning capacity.

Table 4: The Collective Abilities of Women's Organizations

\begin{tabular}{|c|c|c|}
\hline Variables & Respondent's Explanation and Point of Views & Respondent \\
\hline \multirow[t]{5}{*}{$\begin{array}{l}\text { Contributions to } \\
\text { the members }\end{array}$} & $\begin{array}{l}\text { "[1] The organization serves as an agent in linking our members who have } \\
\text { skills into business...; [2] There are...compensations for their contributions } \\
\text { and... we give job opportunities; [3]... we see ourselves as a family, and we } \\
\text { do our best to support each other..." }\end{array}$ & R1 \\
\hline & $\begin{array}{l}\text { "[1] We teach them how to recycle... how to sew, make bedsheets, cutting } \\
\text { and using them as manpower to produce... and earn to support their family; } \\
\text { [2]...they earn from what the have been taught...they also have work; } \\
{[3] \text {... we see ourselves as family, friends, so we help each other..." }}\end{array}$ & $\mathrm{R} 2$ \\
\hline & $\begin{array}{l}\text { "[1] ... any members who lost their job could have food security... } \\
\text { projects. [3] ...providing support, security, and belongingness..." } \\
\text { proje them financial assistance and food proceeds from the farming }\end{array}$ & R3 \\
\hline & $\begin{array}{l}\text { "[1] Money made from the selling of the finished product is shared among } \\
\text { the members... [2] There is an automatic job opportunity given to } \\
\text { members...[3] weekly meetings to discuss struggle and achievement." }\end{array}$ & R4, R10 \\
\hline & "[1]The organization gives the members means to earn extra income, help & R5, R11 \\
\hline
\end{tabular}


DOI: $\underline{10.51386 / 25815946 / \mathrm{ijsms}-\mathrm{v} 4 \mathrm{i} 3 \mathrm{p} 115}$

Volume: 4 Issue: 3

May to June 2021

www.ijjsmsjournal.org

\begin{tabular}{|c|c|c|}
\hline & $\begin{array}{l}\text { them improve their sewing, weaving, cutting, and patterning skills. [2]...we } \\
\text { find a solution and comfort the person." }\end{array}$ & \\
\hline & $\begin{array}{l}\text { "It provides sustainable livelihood to its members, while members also help } \\
\text { other people." }\end{array}$ & R6, R8 \\
\hline & $\begin{array}{l}\text { "[1]...we give loan and assistance to members when need... [2]...to get more } \\
\text { support from government and other agencies... [3]...when members have } \\
\text { problems...we visit..." }\end{array}$ & R7, R9 \\
\hline \multirow[t]{7}{*}{$\begin{array}{l}\text { Attainment of } \\
\text { goals }\end{array}$} & $\begin{array}{l}\text { "[1] The organization has moved from zero...to hero for its members.; [2] } \\
\text { Gain additional market and opportunities... and adapt the use of } \\
\text { technology...; [3] ...there are areas need to improve such as } \\
\text { communication, data keeping, and other essentials." }\end{array}$ & $\mathrm{R} 1$ \\
\hline & $\begin{array}{l}\text { "[1] ...we started with } 48 \text { members, now we have } 3,017 ;[2] \text { Increasing } \\
\text { members, satisfying the member's needs and providing for the society } \\
\text { also...; [3] we want to be recognized, we aim for international } \\
\text { recognitions..." }\end{array}$ & $\mathrm{R} 2$ \\
\hline & $\begin{array}{l}\text { "[1]... The organization helped...in feeding and providing for so many people } \\
\text { in the society and its members... [2] We have been able to reach a larger } \\
\text { number of population in the society..." }\end{array}$ & R3 \\
\hline & “Social and financial struggles of the members have been achieved." & $\mathrm{R} 4$ \\
\hline & 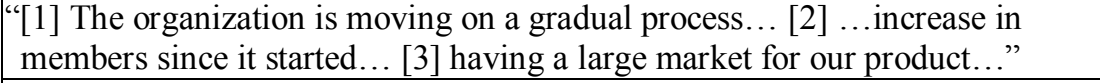 & $\begin{array}{l}\text { R5, R8, R9, } \\
\text { R10 }\end{array}$ \\
\hline & "Very successful..." & R6 \\
\hline & $\begin{array}{l}\text { "[1] There have been successes in social development, not so much with } \\
\text { money, but as long as to help family and community improvement. [2] } \\
\text { Some members learned a lot...cook, sew, and do business." }\end{array}$ & R7, R11 \\
\hline \multirow[t]{7}{*}{$\begin{array}{l}\text { Key values } \\
\text { imparted to } \\
\text { members }\end{array}$} & $\begin{array}{l}\text { "[1]... we have to be family-oriented; [2] confidence, togetherness, family- } \\
\text { oriented, Christ-like. [3] putting up different workshops, teambuilding } \\
\text { activities, and providing opportunities for members..." }\end{array}$ & $\begin{array}{l}\text { R1, R5, R7, } \\
\text { R9, R11 }\end{array}$ \\
\hline & $\begin{array}{l}\text { "[1] Members should be vigilant of all things we do... should not lie... ask for } \\
\text { help...honesty and love; [2] Christ-like honesty, love, focus and vigilant; } \\
\text { [3] ... we teach them to be good leaders, honesty..." }\end{array}$ & $\mathrm{R} 2$ \\
\hline & $\begin{array}{l}\text { "[1] ... making sure the society is a place free from hunger...and crimes... } \\
{[2] \text {...upholding ethics of the organization...equality and fairness..." }}\end{array}$ & R3 \\
\hline & "[1] Honesty and hardworking... [2]...focused the better learning of skills." & $\mathrm{R} 4$ \\
\hline & “Cooperation and unity...creativity and self-confidence.” & R6 \\
\hline & $\begin{array}{l}\text { "[1]They have patience, kindness, discipline, efficiency [2] ...pink ladies } \\
\text { stands for patience, indestructibility, nobility, kindness, lenient, } \\
\text { accountability, discipline, integrity, efficiency, simplicity." }\end{array}$ & R8 \\
\hline & "Cultural dialect, food, and activities, and the language." & R10 \\
\hline \multirow[t]{5}{*}{$\begin{array}{l}\text { Leadership } \\
\text { capacitation }\end{array}$} & $\begin{array}{l}\text { "[1]...long time member, having experience...[2] to improve their leadership } \\
\text { skills." }\end{array}$ & $\mathrm{R} 1, \mathrm{R} 7, \mathrm{R} 8$ \\
\hline & $\begin{array}{l}\text { "...have the leadership skills and problem-solving skills...gain respect...to } \\
\text { help in running the organization to achieve success." }\end{array}$ & $\mathrm{R} 2, \mathrm{R} 5, \mathrm{R} 11$ \\
\hline & $\begin{array}{l}\text { "...have some special responsibilities to perform duties or assignments... an } \\
\text { edge in decision-making and welcomes opinions..." }\end{array}$ & R3 \\
\hline & $\begin{array}{l}\text { "Good communication and time-management skills, known the organization } \\
\text { very well, long-term member." }\end{array}$ & R4, R9 \\
\hline & $\begin{array}{l}\text { "...Willing to render services...someone to prepare and process papers... and } \\
\text { inform the members on the progress of the organization." }\end{array}$ & R6, R10 \\
\hline
\end{tabular}

They offered job opportunities to their members by utilizing their skills (R1). They also trained their members with a specific set of skills such as sewing, making bed sheets, and cutting to create livelihood (R2). This is affirmed by the findings of Garry and Pearsall (1989). They found out that the women can improve themselves through active engagement with them and provide opportunities while performing their roles as a wife or mother 


\section{DOI: $\underline{10.51386 / 25815946 / i j s m s-v 4 i 3 p 115}$}

to their families. Accordingly, they can maximize their available resources and time and use them effectively so long as they can do so.

The women in organizations have shown their capacity to attain their collective goals. They elaborated several successes of these organizations amidst the challenges they have encountered. They mentioned that from zero, they were able to procure resources, and they were able to capture opportunities and markets for their products. However, they admitted that there are still areas for improvement, but they can prosper and succeed through their collective efforts and abilities.

The findings are in line with the study of Double and Supriya (2010), which reveals that women's organizations can see opportunities amidst their difficulties and capacitate their members to improve their condition.

Notably, women's organizations have imparted values and impacted the confidence of the members in their dealings with their family, with their work and clients. This is affirmed by Huntsman and Wulf (2006) work, which highlighted collective institutions and social networks as primary sources of belongingness, engagement, and value. Burke and Collins (2001) further added that women adopt ethical principles and values from their organizations through their relevant activities and collaborations. Seemingly, this study shows that women's organizations create activities such as workshops, team building, and providing opportunities for the members to uphold their organizational and community ethics and values.

Furthermore, women's organizations manifest their capacity to train their members in developing good communication and time-management skills. This eventually helps them to deliver their services to the clients and their organization effectively. Some women members showcased their leadership abilities in terms of their family management, and they as well portrayed themselves as resourceful individuals in the community. Interestingly, this study resonates well with Kumar's (2010) findings, which emphasize on social capital entities playing vital roles in enabling future leaders by providing avenues for self-development and working for the common good through collaboration.

\section{The Social Connection through the Women's Organization}

The social connection that was created through women's organization was derived from women leaders and managers who discuss how women organizations establish social connections through the means of: (a) the reasons of the members to join the organization; (b) the activities of the women's organizations that could bind the member's relationships; (c) the services of members that help in the realization of the organization's goals; (d) resources rendered by the members that become a relational asset; (e) task and responsibilities; and (f) monetary contributions.

Table 5: The Social Connection through the Women's Organization

\begin{tabular}{|c|c|c|}
\hline Variables & Respondent's Explanation and Point of Views & Respondent \\
\hline \multirow[t]{6}{*}{$\begin{array}{l}\text { Reasons for } \\
\text { membership }\end{array}$} & $\begin{array}{l}\text { "To build a market, increase their opportunities, security, creating } \\
\text { awareness, and culture development." }\end{array}$ & $\mathrm{R} 1$ \\
\hline & $\begin{array}{l}\text { "...to enjoy the benefit of the organization like helping them find } \\
\text { sponsors to train their children in school... to learn skills like sewing and } \\
\text { cooking." }\end{array}$ & $\begin{array}{l}\mathrm{R} 2, \mathrm{R} 7, \mathrm{R} 8, \\
\mathrm{R} 9\end{array}$ \\
\hline & $\begin{array}{l}\text { "[1] Members join to pull their resources together... [2] ...to offer ideas } \\
\text { in running the organization..." }\end{array}$ & R3, R11 \\
\hline & "...they need financial support." & R4, R5 \\
\hline & "For employment and friendship/ bonding among members." & R6 \\
\hline & "To know each other like identifying our tribe..." & R10 \\
\hline \multirow[t]{5}{*}{ Activities } & $\begin{array}{l}\text { "We have our meetings, seminars, workshops...party like gathering with } \\
\text { all members ... also sponsor some kids." }\end{array}$ & $\begin{array}{l}\text { R1, R6, } \\
\text { R10, R11 }\end{array}$ \\
\hline & $\begin{array}{l}\text { "Medical missions and providing essential needs of members, doing } \\
\text { cooking lessons, free checkup for members. We also do gardening." }\end{array}$ & R2 \\
\hline & $\begin{array}{l}\text { "[1] A monthly contribution...to execute organization plan. [2] A weekly } \\
\text { reach out in the society with agricultural products..." }\end{array}$ & R3, R9 \\
\hline & "Day-to-day cloth making and design planning." & R4, R5 \\
\hline & $\begin{array}{l}\text { "Creating livelihood, conduct meetings, and know their problems...to } \\
\text { gain more knowledge." }\end{array}$ & R7, R8 \\
\hline
\end{tabular}


DOI: $\underline{10.51386 / 25815946 / i j s m s-v 4 i 3 p 115}$

Volume: 4 Issue: 3

May to June 2021

www.ijjsmsjournal.org

\begin{tabular}{|c|c|c|}
\hline \multirow[t]{4}{*}{$\begin{array}{l}\text { Services of } \\
\text { members }\end{array}$} & "...they are assigned with duties when it is required." & $\begin{array}{l}\text { R1, R2; R3, } \\
\text { R6 }\end{array}$ \\
\hline & "...upon learning the skills, they provide services." & R4, R9 \\
\hline & "They contribute their time, labor and also advertise our product ..." & $\mathrm{R} 5, \mathrm{R} 7$, \\
\hline & $\begin{array}{l}\text { "... we are still trying to convince them to be more active to share with } \\
\text { other members." }\end{array}$ & R10 \\
\hline \multirow{5}{*}{$\begin{array}{l}\text { Resources } \\
\text { rendered by } \\
\text { members }\end{array}$} & $\begin{array}{l}\text { "...members render skills, time, workforce, and financial contributions to } \\
\text { sustain the organization." }\end{array}$ & $\mathrm{R} 1, \mathrm{R} 7, \mathrm{R} 10$ \\
\hline & $\begin{array}{l}\text { "Members render labor when there is available work...they also give } \\
\text { their times and efforts in ensuring that we finish the job order." }\end{array}$ & $\mathrm{R} 2$ \\
\hline & $\begin{array}{l}\text { "Members...pull their money together...time-to perform their } \\
\text { duty...Skills and labor....also contribute to making sure that some jobs } \\
\text { are done..." }\end{array}$ & $\begin{array}{l}\text { R3, R5, R6, } \\
\text { R9 }\end{array}$ \\
\hline & "Time is mostly given by members...to assist in the learning." & $\mathrm{R} 4$ \\
\hline & $\begin{array}{l}\text { "Once you are a member, you have to help in the processing of the } \\
\text { product, selling, cleaning, and others buy the product." }\end{array}$ & $\mathrm{R} 8$ \\
\hline \multirow[t]{4}{*}{$\begin{array}{l}\text { Tasks and } \\
\text { responsibilities }\end{array}$} & $\begin{array}{l}\text { "Tasks and responsibilities are assigned based on the skills... and the time } \\
\text { a member is available and can devote." }\end{array}$ & $\begin{array}{l}\text { R1, R6, R7, } \\
\text { R9 }\end{array}$ \\
\hline & $\begin{array}{l}\text { "...to talk about our product to people and also making use of our } \\
\text { products." }\end{array}$ & R2, R5, R8 \\
\hline & $\begin{array}{l}\text { "all members are assigned with specific tasks to make the workflow } \\
\text { easier...division of labor is paramount in reaching goals." }\end{array}$ & R3, R10 \\
\hline & "There are, and it is being interchanged on a weekly basis." & R4 \\
\hline \multirow[t]{2}{*}{$\begin{array}{l}\text { Monetary } \\
\text { contributions }\end{array}$} & $\begin{array}{l}\text { "...members pay dues which we use in sustaining the organizations and } \\
\text { to give back to the members when there is a need..." }\end{array}$ & $\begin{array}{l}\text { R1, R2; R3, } \\
\text { R5, R6, R7, } \\
\text { R8, R9, } \\
\text { R10, R11 }\end{array}$ \\
\hline & "None, only registration in the organization." & R4 \\
\hline
\end{tabular}

Every women member have their specific reasons for joining their respective organizations. In general, they would want to enjoy the benefits and privileges being provided by their institution. Joining the organization also allows them to express themselves as a social entity. This contention is affirmed by Putnam (2000), who mentioned that social capital is an entity where the members could benefit and express themselves, such as trust, norms, and networks that could enhance societal efficiency through coordinated activities.

Women organizations organize activities that would further enhance the members' aspirations and pursue the organization's purpose. The activities including skills development; hence, they organize meetings, seminars, and workshops. Additionally, they also organize activities to further strengthen their collaboration by setting social gatherings and community outreach to share their community's concerns. According to Temkin and Rohe's (1998) study, activities that work promote social connection that are vital to women's organizations' stability, social gatherings and neighbourhood activities help social capital to thrive and further develop.

Moreover, when the members join the organization, they understood that they would help the organization's activities such as processing products, selling, cleaning, and buying their products. The members are also expected to contribute dues and financial support to pursue their purpose and activities. Their monetary contribution is vital to run and sustain their services, such as loans. Arum (2010) study echoes similar results. The study reveals that member of social capital entities are willing to contribute their services and resources when they realize and perceive the benefits of doing so.

6. The Value of Women's Organizations: The Net Present Value Method- the descriptive statistics of the financial indicators relevant in determining women's organizations' net present value. It shows the actual financial data provided by managers and officers of women's organizations in Baguio City regarding their startup cost, revenue, expenses, working capital (WC) changes, and capital expenditures (CAPEX), annual growth, and return on equity. 
DOI: $\underline{10.51386 / 25815946 / \mathrm{ijsms}-\mathrm{v} 4 \mathrm{i} 3 \mathrm{p} 115}$

Volume: 4 Issue: 3

May to June 2021

www.ijjsmsjournal.org

Table 6: Descriptive Statistics of the Financial Indicators of Women's Organizations' Value

\begin{tabular}{|c|c|c|c|c|c|c|c|c|}
\hline No. & $\begin{array}{l}\text { Start-up } \\
\text { Cost }\end{array}$ & Revenue & Expenses & $\begin{array}{l}\text { Non-Cash } \\
\text { Expenses }\end{array}$ & $\begin{array}{l}\text { WC } \\
\text { Changes }\end{array}$ & CAPEX & $\begin{array}{l}\text { Annual } \\
\text { Growth }\end{array}$ & $\begin{array}{l}\text { ROE } \\
\%\end{array}$ \\
\hline 1 & 10,000 & 180,000 & 27,000 & 30,000 & 30,000 & 260,000 & $15 \%$ & $18 \%$ \\
\hline 2 & 11,500 & 160,000 & 48,000 & 32,000 & 100,000 & 35,000 & $40 \%$ & $20 \%$ \\
\hline 3 & 20,000 & 120,000 & 35,000 & 80,000 & 40,000 & 300,000 & $20 \%$ & $17 \%$ \\
\hline 4 & 7,500 & 4,800 & 3,000 & 6,000 & 10,000 & 200,000 & $20 \%$ & $16 \%$ \\
\hline 5 & 32,000 & 45,000 & 28,000 & 15,000 & 20,000 & 80,000 & $25 \%$ & $17 \%$ \\
\hline 6 & 10,000 & 230,000 & 67,000 & 90,000 & 45,000 & 200,000 & $30 \%$ & $18 \%$ \\
\hline 7 & 15,000 & 60,000 & 13,000 & 34,000 & 30,000 & 150,000 & $10 \%$ & $17 \%$ \\
\hline 8 & 4,000 & 130,000 & 40,000 & 23,000 & 100,000 & 150,000 & $30 \%$ & $19 \%$ \\
\hline 9 & 2,500 & 36,000 & 5,000 & 28,000 & 30,000 & 60,000 & $40 \%$ & $20 \%$ \\
\hline 10 & 3,000 & 78,000 & 15,000 & 35,000 & 15,000 & 150,000 & $40 \%$ & $21 \%$ \\
\hline 11 & 13,000 & 50,000 & 35,000 & 20,000 & 35,000 & 115,000 & $25 \%$ & $22 \%$ \\
\hline Mean & 11,682 & 99,436 & 28,727 & 35,727 & 41,364 & 154,546 & $28 \%$ & $9 \%$ \\
\hline $\begin{array}{l}\text { Std. } \\
\text { Dev. }\end{array}$ & 8,583 & 69,974 & 19,251 & 25,958 & 30,748 & 81,745 & $11 \%$ & $2 \%$ \\
\hline Min. & 2,500 & 4,800 & 3,000 & 6,000 & 10,000 & 35,000 & $10 \%$ & $16 \%$ \\
\hline Max. & 32,000 & 230,000 & 67,000 & 90,000 & 100,000 & 300,000 & $40 \%$ & $22 \%$ \\
\hline $\begin{array}{l}\text { Norm. } \\
\text { P-value }\end{array}$ & 0.12 & 0.62 & 0.76 & 0.01 & 0.01 & 0.84 & 0.13 & 0.53 \\
\hline $\begin{array}{l}\text { Norm. } \\
\text { Desc. }\end{array}$ & yes & Yes & Yes & No & No & Yes & Yes & Yes \\
\hline
\end{tabular}

The most of the women's organizations have started with minimal start-up capital (Mean=P11,681; $\operatorname{Min}=\mathrm{P} 2,500 ; \operatorname{Max}=\mathrm{P} 32,000)$, which indicates that they had limited capacity to start-up their business enterprise. On the other hand, they were capable of generating revenue (Mean=尹99,436; Min=P4,800; Max=尹230,000) that could sustain their operating expenses (Mean=P28,727.27; Min=尹3,000; Max=P67,000). This seems to portray that women's organizations are able to collect revenues and pay for their necessary expenses. More so, women's organization can pursue their collective goals by living out their principles and values even though they have limited resources.

Moreover, women's organizations expect to have growth in terms of their operation (Mean=28\%; Min=10\%; Max=40\%). Despite their limited resources, they are confident that they can successfully grow in their operation and as a business enterprise through their principle-based organization. Lastly, the women's organization also provides an acceptable, expected return on equity (Mean=29\%; Min=16\%; Max=22\%). This indicates that women's organizations pursue a positive return on equity on every financial decision they make. They intend to provide a positive financial return to the money invested by the organization's women members. 
DOI: $\underline{10.51386 / 25815946 / \mathrm{ijsms}-\mathrm{v} 4 \mathrm{i} 3 \mathrm{p} 115}$

Volume: 4 Issue: 3

May to June 2021

www.ijsmsjournal.org

Finally, the women's organization value can be calculated using the net present social value (NPSV) technique to assess whether women's organizations have favorable economic value. The calculation is as follows:

\begin{tabular}{|l|c|}
\hline \multirow{2}{*}{ Financial Information } & Mean Value \\
\hline Revenue & $99,436.36$ \\
\hline \hline Less: Expenses & $28,727.27$ \\
\hline \hline Net Operating Income & $70,709.09$ \\
\hline \hline Add: Non-Cash Expenses & $35,727.27$ \\
\hline \hline Less: Working Capital Changes & $41,363.64$ \\
\hline \hline Operating Free Cash Flow & $65,072.73$ \\
\hline \hline Less: CAPEX & $154,545.45$ \\
\hline \hline Free Cash Flow to the Firm & $(89,472.73)$ \\
\hline \hline & \\
\hline \hline Expected Annual Growth & $28 \%$ \\
\hline \hline Expected ROE & $29 \%$ \\
\hline \hline Start-up Cost & $11,681.82$ \\
\hline
\end{tabular}

The financial information provided by the women's organizations provides a negative free cash flow to the firm (FCFF); hence the value of women's organizations cannot be calculated. This also implies that women's organization's value is negative since the cash generated by their operations could not sustain the required capital expenditures. This means that they need additional financing requirements coming from the members or external creditors to have adequate long-term assets to support their business operation fully.

On the other hand, financial information provides a positive operating free cash flow (OFCF), which measures women's organizations' operational performance. The OFCF indicates that women's organizations could sustain to pay their operating expenses. They could acquire additional short-term resources to support the increase in the demands for their products. Hence, the value of women's organizations can be explored in terms of their operation value. Following the NPV formula:

$N P V=\frac{\sum_{t} C F_{t}(1+g)}{K-g}-C$

Where: $\mathrm{CF}_{\mathrm{t}}$ is substituted by operating free cash flow

\begin{tabular}{llll}
$\mathrm{NPV}_{\text {Operation }}$ & $=\frac{\mathrm{OFCF}(1+\mathrm{g})}{\mathrm{ROE}-\mathrm{g}}-$ & Start-up Cost \\
$\mathrm{NPV}_{\text {Operation }}$ & $=\frac{65,072.73(1+28 \%)}{29 \%-28 \%}$ & $11,681.82$ \\
$\mathrm{NPV}_{\text {Operation }}$ & $=$ & $10,183,045.45$ & \\
\hline \hline
\end{tabular}

The positive and highly favourable NPV of the operations of women's organizations indicates that women's organizations bring a positive social benefit derived from their business operations and activities. The result shows of growing positive operating free cash flows, and they are able to compensate for the required return on equity through their business operations. It also shows that women's organizations' business operations can compensate the amount invested by the members and generate economic wealth for the women members. Hence, the overall result shows that establishing women's organizations is a worthwhile endeavour, and it depicts a realistic scenario of social capital. The result is corroborated by Sappleton's (2009) findings, which indicates women's organizations as social capital by providing high contributions to their members through their business operation. Similarly, Lowndes' (2006) findings reveal that women's organizations are highly 
DOI: $\underline{10.51386 / 25815946 / \mathrm{ijsms}-\mathrm{v} 4 \mathrm{i} 3 \mathrm{p} 115}$

Volume: 4 Issue: 3

May to June 2021

www.ijjsmsjournal.org

recognized as social capital since they continuously encourage women's participation and show sustainable business operation.

7. The Value of Women in a Women's Organizations: The NPSV Method - the descriptive statistics of the women's estimated monetary contribution to their respective women's organizations and their willingness to accept (WTA) for the services and resources that they are rendering. Additionally, it also presents descriptive statistics on the willingness to pay (WTP) of women's organizations on the services and resources being rendered by women.

Table 7: Descriptive Statistics of the Indicators for Estimating Women's Value

\begin{tabular}{|l|c|c|c|l|}
\hline Descriptive Statistics & \multicolumn{1}{l|}{ WTP } & WTA & Paid Contribution & $\begin{array}{l}\text { Expected } \\
\text { Growth }\end{array}$ \\
\hline Mean & $7,227.27$ & $10,855.00$ & $3,151.00$ & $18 \%$ \\
\hline Mode & $8,000.00$ & $13,000.00$ & $5,000.00$ & 0.15 \\
\hline Range & $5,000.00$ & $15,550.00$ & $10,900.00$ & 0.45 \\
\hline Min & $5,000.00$ & $2,950.00$ & 100.00 & $0 \%$ \\
\hline Max & $10,000.00$ & $18,500.00$ & $11,000.00$ & $45 \%$ \\
\hline Norm. P-value & 0.1909954 & 0.121672 & 0.0007275 & 0.001982 \\
\hline Norm. Desc. & Yes & Yes & No & No \\
\hline
\end{tabular}

The women's organizations provide a positive net present social value for their women members as determined in the managers' perceived willingness to pay (WTP). This means that women's services and contributions are valuable to women's organizations. It reveals that the respondent managers are willing to give a positive monetary compensation for their women members. Molyneux (2007) shares similar findings in this study. Accordingly, women are valuable assets in which they contribute community and household labour, which are essential in societal development. Additionally, women are also regarded as financial capital in women's organizations because they are resources that can contribute both tangible and intangible outputs.

Moreover, women provide a willingness to accept the services and resources they contribute to their respective organizations $($ Mean=P7,227.27; Min= $\mathrm{P} 5,000 ; \operatorname{Max}=\mathbf{P} 10,000)$. This provides for a net present social value following the formula:

$N P S V=\frac{\sum_{t} C F_{t}(1+g)}{K-g}-C$

Where: $\mathrm{CF}_{\mathrm{t}}$ is substituted by the willingness to accept

$\mathrm{C}$ is the paid contribution

$\mathrm{ROE}$ is the return on equity expected by women's organizations

$\begin{array}{llllc}\text { NPSV } & =\text { WTA }(1+\mathrm{g}) & - & \text { Paid Contribution } \\ & & \text { ROE }-\mathrm{g} & & \\ \text { NPSV } & = & 10,855(1+18 \%) & - & 3,151.00 \\ \text { NPSV } & & 29 \%-18 \% & & \end{array}$

The result elicits a positive net present social value of women in women's organizations based on the perceived willingness to accept (WTA) of women members. The result reveals that the women members positively value the services and contributions to their respective organizations. This is affirmed in Young's (2012) study, which claims that through social capital networks (e.g., women's organizations), women could contribute through their ability and capacity and also effectively contribute positive economic value through their interactions. It highlights the relevant role of women members who openly give services and contributions to provide a positive 
DOI: $\underline{10.51386 / 25815946 / \mathrm{ijsms}-\mathrm{v} 4 \mathrm{i} 3 \mathrm{p} 115}$

Volume: 4 Issue: 3

May to June 2021

www.ijjsmsjournal.org

monetary value. Notably, Harell (2009) also emphasizes that women are "rich" in various forms of social capital that are found basically in most informal networks of reciprocity.

\section{CONCLUSIONS AND RECOMMENDATION}

\section{A. Conclusion}

Specifically, this study reveals significant insights about women's organizations as a social capital. Women organizations embody the concept of social capital. They have pursued relevant activities not only to cater to the needs of their women members but also to pursue their purpose, vision, and mission as an organization. At the basic development level, women's organizations require social capital as resources of time and space; and safe, accessible public space. While social capital is a resource these women organizations tend to look into their sense of what is acceptable in developing themselves and in achieving their goals. This implies that they embody the social capital through connectedness, co-operation, and sharing of values, which can also occur across many different groups. The study also recommends that the women members must: (1) become proactive in contributing tangible and intangible resources; (2) contribute in improving the organization's FCFF by patronizing their products and services, in advertising their organization as well as their products and services, and in reducing costs if they are directly involved in the business operation; (3) build confidence in themselves and express their self-worth in the organization and the society; and (3) enhance their capacities and capabilities through continuous training, development and education that are being supported by their respective organization.

\section{B. Recommendations}

Based on the study, the researchers suggests that women's organizations must: (1) continuously sustain their business operations and activities by identifying possible products or services that the members can render; (2) improve their free cash flow to the firm (FCFF) by maximizing the capacity of their available equipment, human resources and raw materials in order to generate cash inflows that can sustain the required purchase for longterm assets; (3) enhance their social purposes by identifying the social needs of their members and orient the members during seminars, gatherings and collective activities; (4) expand their target members by recruiting from other nearby localities and create social and livelihood activities that can make their members proactive and earn for a living; and (5) continuously provide societal benefits such as inviting women non-members who can benefit from the social capital and eventually become interested to become part of it.

The study also recommends that the women members must: (1) become proactive in contributing tangible and intangible resources; (2) contribute in improving the organization's FCFF by patronizing their products and services, in advertising their organization as well as their products and services, and in reducing costs if they are directly involved in the business operation; (3) build confidence in themselves and express their self-worth in the organization and the society; and (3) enhance their capacities and capabilities through continuous training, development and education that are being supported by their respective organization

\section{REFERENCES}

[1] Arrivillage M, Beatriz EA, Juan, PS. (2014). Resilience Processes in Women Leading Community Based Organization Providing HIV Prevention Services. UK: Elsevier, HIV \& AIDS Review.

[2] Atkinson, J.W. (1964). An introduction to motivation. Princeton, NJ: Van Nostrand.

[3] Arum I. (2010). Women NGO's and women empowerment in Nigeria, an International multi-disciplinary Journal.Vol.4, No 3b, pp.272-280.

[4] Burke S, Collins K. (2001). Gender differences in leadership styles and management skills Women in management review. Vol.16, No 5, pp. 244- 257.

[5] Cypress B. S. (2017). Rigor or Reliability and Validity in Qualitative Research: Perspectives, Strategies, Reconceptualization, and Recommendations. Dimensions of Critical Care Nursing. Vol. 36, No 4, pp. $253-263$.

[6] Double N, Supriya MV. (2010). Gender differences in the perception of work -life balance, Journal of management. Vol. 5, No 4), pp. 331-342.

[7] Estrada-Claudio S. (2015). Voices and Choices in Reproductive Rights: Scholarship and Activism. In The Social Science in the Asian Century Available at: http://pressfiles.anu.edu.au/downloads/press/p325111/pdf/ch065.pdf. 


\section{DOI: $\underline{10.51386 / 25815946 / i j s m s-v 4 i 3 p 115}$}

Volume: 4 Issue: 3

SAGE Publications, Inc. doi: 10.4135/9781506326139

[9] Ganapati, N.E. (2012). In good company: why social capital matters for women during disaster recovery. Vol.72, No 3, pp. 419-427.doi:10.1111/j.1540-6210.2011.02526.x [8] Feather, 1966

[9] Gapenski, L. C. (2005). Healthcare finance: an introduction to accounting and financial management, $\left(3^{\text {rd }}\right.$ ed). Health administration Press. Chicago: IL.

[10] Garry, A., Pearlsall, M. (1989). Women, knowledge, and reality: explorations in feminist philosophy. Routldge.

[11] Grootaert, C. (1998). Social capital: the missing link.working paper No.3.Washington DC: World Bank.

[12] Hega, M. (2009). In Their Voices: Claiming Women's Spaces in Trade Union Leadership. Unpublished master's thesis. College of Social Work and Community Development, University of the Philippines-Diliman.

[13] Harell, A. (2009). Equal Participation but Separate Paths?: Women's Social Capital and Turnout. Journal of women politics \& policy politics \&policy. Vol. 3, No 1, pp. 1-22. Doi.10.1080/15544770802367770.

[14] Huntsman, M.\& Wulf, V. (2006). Social capital and information technology. The MIT Press.

[15] Jennings, E.H. (1993). Financial Management in Not-for-Profit Businesses. Philippines: Rex Bookstore.

[16] Kamasaki, R. (2017). The contribution of tangible and intangible resources, and capabilities to a firm's profitability and market performance, European Journal of management and business economics. Vol. 26, No 2, pp. 252- 260.

[17] Kumar, R. (2010). Barrier: Absence of a Means to Exploit the Latent Collective Ability for PursuingSuccess. Available at: https://www.managementexchange.com/barrier/absence-means-exploit-latent-collectiveability- pursuing-success.

[18] Lowndes, V. (2000). Women and social capital: A comment on hall's social capital in Britain. British Journal of Political Science. Vol.30, No 31, pp. 23-145.

[19] Maclean, K. (2010). Capitalizing on women's social capital: Women-targeted microfinance in Bolivia. Wiley Online Library, Development, and Change, Vol. 41, No 3, pp. 495-515.

[20] McElroy, M. (2000). Social Innovation Capital. Journal of Intellectual Capital. Vol. 3, No: 1, pp. 10 - 17.

[21] Molyneux, M. (2000). Gender and the Silences of Social Capital: Lessons from Latin America. Vol. 33, No 2, pp. 67-188.

[22] Mpanje, D., Gibons, P., \& McDermott, R. (2018). Social capital in vulnerable urban settings: an analytical framework. Journal of Internationa Humanitarian Action. Vol. 3, No 4, 243 - 256. doi.org/10.1186/s41018-018-0032-9.

[23] Narayan, D., Cassidy, M. F. (2001). A dimensional approach to measuring social capital: development and validation of a social capital inventory. Current Sociology. Vol 49, No 3, pp. 59-102.

[24] Odurukwe, S. N., Asiabaka, C. C., Ugwoke, F. O., Ehirim, N. C., \& EjioguOkereke, E. N. (2007). Role of women organizations in community development: A case study of Orlu agricultural zone, Imo state. International Journal of Agriculture and Development Vol. 9, pp. 85-91.

[25] Organization for Economic Co-operation and Development (2001). The Well-being of Nations. The Role of Human and Social Capital. Education and Skills. Accessed from OECD website: https://www.oecd.org/.

[26] Olojede I. Women interest organizations: Encounters with the State on issues of good governance programs, IDS, Department of political science, Lagos state, Nigeria.

[27] Parry, L., and C. A. Peres. (2015). Evaluating the use of local ecological knowledge to monitor hunted tropical-forest wildlife over large spatial scales. Ecology and Society. Vol. 20, No 3, pp. 15.http://dx.doi.org/10.5751/ES-07601-200315.

[28] Putnam, R. (2000). Bowling alone: the Collapse and Revival of American Community. New York: Simon and Schuster. Paperbacks.

[29] Putnam, R. (1993). The Prosperous Community - Social Capital and Public Life. American Prospect. Vol. 13, pp. 35-42.

[30] Sappleton, N. (2009). Entrepreneurs and Social Capital. International Journal of Gender and Entrepreneurship. Vol. 2, No 1, pp. 1756-6266.

[31] Soriola, E. (2017). History of feminism in Nigeria. Available at: htps//www.naija.com.

[32] Stephenson, K. (2018). https:www.prnewswire.com/news-release/social-network-analysis-pioneer-dr-kareen-stephenson-joinstrustsphere-to-build-it-science-advisoy-board-300737871.html.

[33] Taylor, A.J., Stephen, R.G., Kowalski, S.M.,Wilson, C.D., Carlson, J., Scotter, P.V. (2015). An Efficacy Trial of Research-Based Curriculum Materials with Curriculum-Based Professional Development. American Educational Research Journal. Vol. 20, No. 


\section{DOI: $\underline{10.51386 / 25815946 / \mathrm{ijsms}-\mathrm{v} 4 \mathrm{i} 3 \mathrm{p} 115}$}

Volume: 4 Issue: 3

10, pp. 1-34.

[34] Temkin, K., Rohes, W. (1998). Social capital and neighborhood stability: an empirical investigation housing policy debate.Vol. 9 , No 1, pp.61-88.

[35] Tsai, W., Ghoshal, S. (1998). Social capital and value creation: the role of intrafirm networks. Academy of Management Journal. Vol. 42. No 4, pp. 464-76.

[36] Wambua, E.K. (2013). The Role of women's' organizations in empowering women in Mwingi District, Kenya.

[37] Wheeler, J. R., Clement, J. P. (1990). Capital Expenditure Decisions and the Role of the Not-for-Profit Hospital: An Application of a Social Goods Model. Medical Care Review. Vol.47, No 4, pp. 467-486. Doi: 10.1177/107755879004700404.

[38] Woolcok, M., Deepa, N. (2000). Social Capital: Implications for Development Theory, Research, and Policy, the World Bank Research Observer. Vol.15 No 1, pp. 225-249.

[39] World Bank, (2001). World Development Report 2000/2001: Attacking Poverty. Washington, D.C.: The World Bank.

[40] Young, J. (2012). Social Capital and Trust for a Web Environment. USA: Personal Knowledge Capital. 